\title{
Kejadian Infeksi Menular Seksual di Kota Denpasar Tahun 2016
}

\author{
INCIDENCE OF SEXUALLY TRANSMITTED INFECTION IN DENPASAR IN 2016
}

Desak Nyoman Widyanthini ${ }^{1}$, Desak Made Widyanthari ${ }^{2}$, dan Ni Made Dian Kurniasari ${ }^{1}$

${ }^{1}$ Program Studi Sarjana Kesehatan Masyarakat, Fakultas Kedokteran Universitas Udayana, Jl. P.B Sudirman Denpasar 80232, Indonesia

${ }^{2}$ Program Studi Sarjana Keperawatan dan Profesi Ners, Faluktas Kedokteran, Universitas Udayana, Jl. P.B. Sudirman Denpasar 80232, Indonesia

*Email : desakwidyanthini@unud.ac.id

Submitted: 12-09-2019, Revised: 22-09-2019, Revised : 15-10-2019, Accepted : 29-11-2019

\begin{abstract}
The incidence of sexually transmitted infections (STI) that occurred in Denpasar since 2010 until the year 2012 has increased. This study aims to provide an illustration of the incidence of STIs in Denpasar City in 2016 and its influencing factors. This was an analytical study of data derived from medical records of patients who performed STI examination at four public health centers (puskesmas) in Denpasar City from January to December 2016. Data were assessed by univariate and bivariate analyses using chi-square test. The results showed that from a total of 1,397 respondents, 18.2\% were diagnosed as STI positives. The result of bivariate analysis showed that the significant factors for the incidence of STI were female sex worker's customers $(O R=2.3$ 95\% CI: 1.7-3.2; $p<0.001)$, employed respondents (OR=2.2; 95\% CI: 1.7-2.9; $p<0.001)$, male $(O R=1.6 ; 95 \%$ CI: 1.2-2.1; $p=0.001)$ and married $(O R=1.4 ; 95 \% C I: 1.1-1.9 ; p=0.014)$. It is recommended that each puskesmas should conduct community outreach activities especially to female sex worker's customers as one of groups with high risk of STI infections.
\end{abstract}

Keywords: Sexually transmitted infections, public health centers, Denpasar

\begin{abstract}
Abstrak
Sejak tahun 2010 sampai dengan tahun 2012 insiden Infeksi menular seksual (IMS) di Kota Denpasar mengalami peningkatan. Penelitian ini bertujuan untuk memberikan gambaran kejadian IMS di Kota Denpasar tahun 2016 dan faktor-faktor yang mempengaruhinya. Penelitian ini merupakan penelitian analitik dengan pendekatan cross sectional menggunakan data rekam medis pasien yang melakukan pemeriksaan IMS (data tercatat pada SIHA IMS) periode Januari sampai dengan Desember 2016 di empat puskesmas di Kota Denpasar. Analisis dilakukan secara univariat dan bivariate dengan chi square test. Penelitian ini menunjukkan bahwa dari total 1397 reponden, sebanyak 18,2\% didiagnosis positif IMS). Hasil analisa bivariat menunjukkan faktor yang signifikan terhadap kejadian IMS adalah responden pelanggan PSK (OR=2,3 95\% CI: 1,7$3,2 ; \mathrm{p}<0,001)$, bekerja (OR=2,2; 95\% CI: 1,7-2,9; $\mathrm{p}<0,001$ ), laki-laki (OR=1,6; 95\% CI: 1,2-2,1; $\mathrm{p}=0,001)$ dan sudah menikah $(\mathrm{OR}=1,4 ; 95 \% \mathrm{CI}: 1,1-1,9 ; \mathrm{p}=0.014)$. Diharapkan pada masingmasing puskesmas agar kegiatan penjangkauan yang selama ini ada dapat menyasar pelanggan PSK sebagai salah satu kelompok dengan risiko IMS.
\end{abstract}

Kata kunci: Infeksi menular seksual, puskesmas, Denpasar 


\section{PENDAHULUAN}

Infeksi menular seksual

(IMS) merupakan salah satu penyakit infeksi yang ditularkan melalui hubungan seks. Apabila tidak diobati dengan benar infeksi menular seksual akan berdampak pada kesehatan reproduksi ibu, yaitu kanker, infertile, penyakit radang panggul, bahkan kematian serta dapat penyebabkan infeksi pada bayi jika ibunya terinfeksi IMS. Secara tidak langsung, IMS juga turut berperan dalam memfasilitasi penularan infeksi HIV. ${ }^{1}$

Pada tahun 2005 diperkirakan ada 318 juta IMS di dunia, yang terdiri dari infeksi klamidia sebesar 39.690.000 kasus, gonore sebanyak 9.430.000, sifilis sebesar 2,54 juta kasus dan kasus trikomonas sebesar 25.760.000 kasus. ${ }^{2}$ Centers for Disease Control and Prevention (CDC) memperkirakan ada lebih dari 110 juta kasus baru IMS pada laki-laki dan perempuan di dunia. ${ }^{3}$ Menurut World Health Organization (WHO) pada tahun 2008 di seluruh negara terdapat sekitar 250 juta penderita baru IMS. Secara global penyebaran IMS paling tinggi tercatat di Asia Selatan dan Asia Tenggara, disusul kemudian oleh Afrika bagian Sahara, Amerika Latin dan Karibia. Setiap tahun terjadi peningkatan kasus IMS yang disebabkan oleh virus, diantaranya HIV, herpes, HPV dan hepatitis B. ${ }^{2}$ Data terbaru dari the US Centers for Disease Control and Prevention (CDC) pada tahun 2013, di Amerika tercatat 6231 kasus dari 100.000 wanita terinfeksi Chlamydia trachomatis dan Syphilis. ${ }^{3}$ Infeksi klamidia pada wanita sebagian besar disumbangkan oleh kelompok umur 15-24 tahun. Dalam beberapa tahun terakhir ini terlihat adanya kecenderungan peningkatan prevalensi penyakit IMS di berbagai negara termasuk Indonesia. ${ }^{4}$

Pada tahun 2014 jumlah kasus IMS di Indonesia sebanyak 5608 kasus. Survey Demografi dan Kesehatan Indonesia (SDKI) tahun 2012 menunjukkan bahwa kejadian IMS dan atau gejalanya dialami oleh $12 \%$ wanita usia 15-49 tahun yang melaporkan pernah melakukan hubungan seksual secara aktif. ${ }^{5}$ Insiden kasus IMS yang terjadi di Kota Denpasar sejak tahun 2010 sampai dengan tahun 2012 mengalami peningkatan. Jenis IMS yang paling banyak diderita adalah Gonore (32,3\%), disusul Sifilis
$(0,6 \%)$, dan sisanya adalah jenis IMS lainnya. Insiden IMS tertinggi terjadi pada kelompok umur 14-44 tahun (1419 per 100.000 penduduk) dan terendah adalah kelompok umur $<1$ tahun (1 per 100.000 penduduk). Hal ini disebabkan karena usia tersebut merupakan usia yang aktif secara seksual, dimana penularan IMS terjadi memang melalui hubungan seksual. ${ }^{6}$

Layanan IMS yang diberikan di puskesmas di Kota Denpasar meliputi pemeriksaan, pengobatan, konseling perubahan perilaku serta pemberian kondom. Intervensi yang optimal akan dapat tercapai apabila didukung oleh data yang akurat. Pada 19 Desember 2012 Kementerian Kesehatan memberlakukan SIHA (sistem informasi HIV/AIDS dan IMS) secara resmi sebagai satu sistem pencatatan dan pelaporan HIV-AIDS dan IMS dengan menggunakan satu bank data nasional satu pintu yang kredibel dan legal. SIHA adalah langkah penting dalam pengendalian dan penyebaran HIV-AIDS di Indonesia yang digunakan mulai di tingkat kabupaten, propinsi dan nasional. Dalam SIHA semua data pasien tercatat dengan lengkap, mulai dari data demografi sampai data perilaku yang berhubungan dengan kesehatan seksual.

Kejadian infeksi menular seksual disebabkan oleh beberapa faktor, antara lain penyebab penyakit (agent), host (umur, jenis kelamin, pilihan dalam hubungan seksual, status perkawinan dan pemakaian kondom) dan faktor lingkungan (faktor demografi, sosial ekonomi, kebudayaan dan medik). Penelitian ini bertujuan untuk memberikan gambaran kejadian IMS di Kota Denpasar tahun 2016 dan faktor-faktor yang mempengaruhinya.

\section{BAHAN DAN METODE}

Penelitian ini menggunakan rancangan analitik kuantitatif dengan pendekatan cross sectional. Penelitian menggunakan data sekunder, dari data SIHA IMS di empat puskesmas di Kota Denpasar yaitu: Puskesmas II Denpasar Utara, Puskesmas I Denpasar Timur, Puskesmas II Denpasar Selatan dan Puskesmas II Denpasar Barat. Kriteria inklusi lokasi penelitian puskesmas mempergunakan SIHA IMS sebagai alat pencatatan dan pelaporan kasus IMS dan jumlah kunjungan IMS paling banyak pada 
masing-masing kecamatan di Kota Denpasar.

Populasi dalam penelitian ini adalah seluruh pasien yang berkunjung di klinik IMS di empat puskesmas di Kota Denpasar sejak Bulan Januari 2016 sampai dengan Desember 2016. Penelitian ini menggunakan total sampling, yaitu seluruh pasien IMS yang tercatat pada SIHA IMS di empat puskesmas Kota Denpasar pada tahun 2016, dengan kriteria eksklusi: bukan kunjungan pertama dan dalam keadaan hamil. Data dianalisis secara univariat dan bivariate (uji chi square), dengan menggunakan SPSS 18. Penelitian ini telah dinyatakan laik etik oleh Komisi Etik Penelitian Fakultas Kedokteran Universitas Udayana/Rumah Sakit Umum Pusat Sanglah Denpasar dengan no etik 1889/UN 14.2/ $\mathrm{KEP} / 2017$.

\section{HASIL}

Jumlah sampel dalam penelitian ini adalah 1397 orang dengan karakteristik seperti pada Tabel 1. Sampel paling banyak berasal dari data SIHA IMS di Puskesmas II Denpasar Selatan, yaitu sebanyak 42,3\%. Mayoritas sampel penelitian ini berjenis kelamin perempuan $(69,6 \%)$, berusia $\leq 28$ tahun $(50,8 \%)$ dan bekerja pada sektor swasta $(50,5 \%)$. Sebanyak $49,6 \%$ responden berpendidikan SMA dan 48,5\% sampel telah menikah. Dilihat dari faktor risiko, sebanyak 28,0\% adalah wanita pekerja seks (WPS), 17,3\% adalah pelanggan WPS, 14,0\% adalah lelaki seks dengan lelaki (LSL) atau waria, sementara $40,7 \%$ sisanya tidak termasuk ke dalam kelompok berisiko. Sebagian besar responden mengaku pernah berhubu ngan seksual $(82,4 \%)$, dan dari jumlah tersebut sebagian besar pula tidak menggunakan kondom saat hubungan seksual terakhir (80,1\%). Dari 1397 sampel yang terdata pada SIHA IMS, 18,2\% diantaranya terdiagnosis positif menderita infeksi menular seksual. Jenis IMS yang diderita antara lain servisitis, herpes genital, sifilis, trikomonas, urethritis GO dan urethritis non GO. Analisis varibel jenis kelamin, umur, pendidikan, pekerjaan, status pernikahan, faktro risiko dan penggunaan kondom pada hubungan seksual terakhir sebagai faktorfaktor yang mempengaruhi kejadian infeksi menular seksual ditentukan berdasarkan nilai $\mathrm{p}$, nilai odd ratio (OR), dan 95\% CI dari OR dengan menggunakan uji chi square. Tabel 5.2
Menunjukkan bahwa dari tujuh faktor yang dianalisis, terdapat empat faktor yang secara independent mempengaruhi dengan kejadian IMS. Peluang kejadian IMS paling besar ditemukan pada variabel faktor risko. Sebanyak $30,2 \%$ pelanggan WPS didiagnosis positif IMS, sementara pada kelompok lain seperi LSL/waria, WPS dan lainnya sebanyak $15,7 \%$ positif IMS. Peluang terjadinya IMS ditemukan 2,3 kali lebih besar pada pelanggan WPS dibandingkan LSL/ waria, WPS dan lainnya $(\mathrm{OR}=2,3 ; 95 \% \mathrm{CI}=1,7-$ $3,2 ; \mathrm{p}<0,001)$.

Selanjutnya adalah variabel pekerjaan, dimana sebanyak 23,7\% sampel yang berkerja positif mengalami IMS dan 12,4\% sampel yang tidak bekerja positif didiagnosis IMS. Peluang terjadinya IMS lebih besar 2,2 kali pada sampel yang berkerja dibandingkan sampel yang tidak bekerja $(\mathrm{OR}=2,2 ; 95 \% \mathrm{CI}=1,7-2,9 ; \mathrm{p}<0,001)$.

Sampel yang berjenis kelamin laki-laki mengalami IMS sebanyak $23,3 \%$ dan hanya $15,9 \%$ sampel perempuan yang terdiagnosis positif IMS. Peluang terjadinya IMS ditemukan 1,6 kali lebih besar pada laki-laki dibandingkan dengan perempuan $(\mathrm{OR}=1,6 ; 95 \% \mathrm{CI}=1,2-2,1$; $\mathrm{p}=0,001)$.

Sebanyak 20,8\% sampel yang menikah positif terkena IMS, sementara $15,7 \%$ sampel dengan status janda/duda atau belum menikah positif terkena IMS. Hasil analisis statisti menunjukkan sampel yang menikah 1,4 kali lebih besar berpeluang terinfeksi IMS dibandingkan sampel dengan status janda/duda atau belum menikah $(\mathrm{OR}=1,4 ; 95 \% \mathrm{CI}=1,1-1,9 ; \mathrm{p}=0,014)$.

Dilihat dari variabel umur, sebanyak $16,4 \%$ sampel yang berumur $\leq 28$ tahun dan sebanyak $20,1 \%$ sampel yang berumur $>28$ tahun positif terkena IMS. Sampel dengan pendidikan rendah mengalami IMS sebanyak 17,8\% sementara sampel dengan pendidikan tinggi mengalami IMS sebanyak 18,4\%. Jika dilihat dari variabel pemakaian kondom pada hubungan seksual terakhir, sebanyak 20,1\% sampel yang tidak menggunakan kondom dan 21,0\% sampel yang menggunakan kondom terdiagnosis positif IMS. Akan tetapi pada ketiga variabel tersebut (umur, pendidikan dan pemakan kondom pada hubungan seksual terakhir) dijumpai tidak bermakna secara statistik, masing-masing dengan nilai $\mathrm{p}=0,073 ; 0,755$ dan 0,763 . 
Tabel 1. Karakteristik Sampel Penelitian

\begin{tabular}{|c|c|}
\hline Karakteristik & Jumlah (\%) \\
\hline $\begin{array}{l}\text { Asal puskesmas } \\
\text { Puseksmas II Denpasar Utara } \\
\text { Puskesmas I Denpasar Timur } \\
\text { Puskesmas II Denpasar Selatan } \\
\text { Puskesmas II Denpasar Barat* }\end{array}$ & $\begin{array}{l}174(12,5) \\
221(15,8) \\
591(42,3) \\
411(29,4)\end{array}$ \\
\hline $\begin{array}{l}\text { Jenis Kelamin } \\
\text { Laki-laki } \\
\text { Perempuan }\end{array}$ & $\begin{array}{l}424(30,4) \\
973(69,6)\end{array}$ \\
\hline $\begin{array}{l}\text { Umur } \\
\qquad \begin{array}{l}\text { Median (IQR) } \\
\leq 28 \text { th } \\
>28 \text { th }\end{array}\end{array}$ & $\begin{array}{l}28(23-36) \\
709(50,8) \\
688(49,2)\end{array}$ \\
\hline $\begin{array}{l}\text { Pendidikan } \\
\text { SD } \\
\text { SMP } \\
\text { SMA } \\
\text { PT }\end{array}$ & $\begin{array}{l}223(16,0) \\
306(21,9) \\
693(49,6) \\
175(12,5)\end{array}$ \\
\hline $\begin{array}{l}\text { Pekerjaan } \\
\text { Tidak bekerja } \\
\text { Swasta } \\
\text { Pegawai negeri sipil } \\
\text { Siswa/mahasiswa }\end{array}$ & $\begin{array}{l}640(45,8) \\
706(50,5) \\
12(0,9) \\
39(2,8)\end{array}$ \\
\hline $\begin{array}{l}\text { Status pernikahan } \\
\text { Menikah } \\
\text { Janda/duda } \\
\text { Belum menikah }\end{array}$ & $\begin{array}{l}678(48,5) \\
219(15,7) \\
500(35,8)\end{array}$ \\
\hline $\begin{array}{l}\text { Faktor risiko } \\
\text { LSL/waria } \\
\text { WPS } \\
\text { Pelanggan WPS } \\
\text { Lain-lain }\end{array}$ & $\begin{array}{l}196(14,0) \\
391(28,0) \\
242(17,3) \\
568(40,7)\end{array}$ \\
\hline $\begin{array}{l}\text { Pernah berhubungan seksual } \\
\text { Ya } \\
\text { Tidak }\end{array}$ & $\begin{array}{c}1151(82,4) \\
246(17,6)\end{array}$ \\
\hline $\begin{array}{l}\text { Penggunaan kondom pada hubungan seksual terakhir** } \\
\text { Tidak } \\
\text { Ya }\end{array}$ & $\begin{array}{l}922(80,1) \\
229(19,9)\end{array}$ \\
\hline $\begin{array}{l}\text { Diagnosis IMS } \\
\text { Positif } \\
\text { Negatif }\end{array}$ & $\begin{array}{c}254(18,2) \\
1143(81,8)\end{array}$ \\
\hline
\end{tabular}

*Hanya data SIHA IMS bulan Januari, Februari, Maret, April, Desember 2016

**Dari jumlah sampel yang pernah berhubungan seksual

Tabel 2. Faktor-faktor yang Mempengaruhi Kejadian IMS

\begin{tabular}{|c|c|c|c|c|c|}
\hline \multirow[b]{2}{*}{ Karakteristik } & \multicolumn{2}{|c|}{ Diagnosis } & \multirow[b]{2}{*}{ Nilai $p$} & \multirow[b]{2}{*}{ Crude OR } & \multirow[b]{2}{*}{$95 \% \mathrm{CI}$} \\
\hline & $\begin{array}{l}\text { Positif } \\
\text { n (\%) }\end{array}$ & $\begin{array}{c}\text { Negatif } \\
\text { n (\%) }\end{array}$ & & & \\
\hline \multicolumn{6}{|l|}{ Jenis Kelamin } \\
\hline Laki-laki & $99(23,3)$ & $325(76,7)$ & 0,001 & 1,6 & $1,2-2,1$ \\
\hline Perempuan & $155(15,9)$ & $818(84,1)$ & & & \\
\hline \multicolumn{6}{|l|}{ Umur } \\
\hline$\leq 28$ th & $116(16,4)$ & $593(83,6)$ & 0,073 & 0,8 & $0,6-1,0$ \\
\hline$>28$ th & $138(20,1)$ & $550(79,9)$ & & & \\
\hline \multicolumn{6}{|l|}{ Pendidikan } \\
\hline Rendah (SD, SMP) & $94(17,8)$ & $435(82,2)$ & 0,755 & 1,0 & $0,7-1,3$ \\
\hline Tinggi (SMA, PT) & $160(18,4)$ & $708(81,6)$ & & & \\
\hline
\end{tabular}




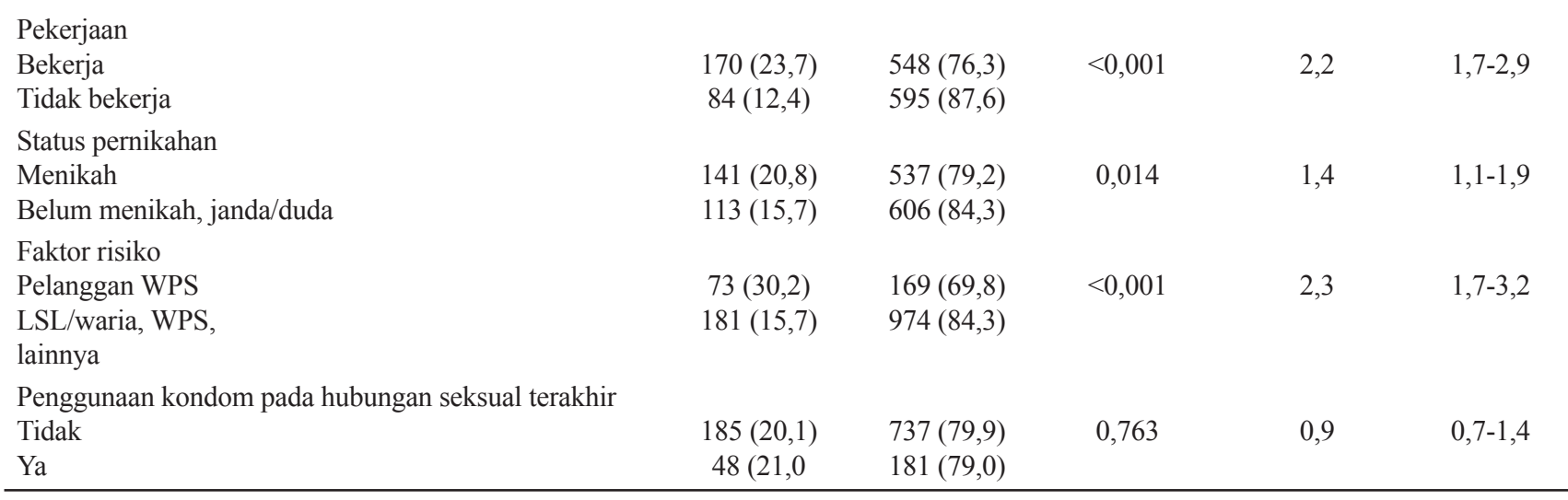

\section{PEMBAHASAN}

Hasil penelitian ini menunjukkan bahwa faktor-faktoryang mempengaruhi kejadian IMS di Kota Denpasar Tahun 2016 adalah jenis kelamin, status pernikahan, faktor risiko dan pekerjaan. Pada penelitian ini dijumpai bahwa peluang lakilaki untuk terinfeksi IMS lebih besar daripada perempuan. Setyowulan menyatakan bahwa pada kelompok umur tertentu angka kesakitan IMS pada laki-laki lebih tinggi dibandingkan perempuan. Adanya perbedaan susunan anatomi organ tubuh tertentu menyebabkan tingkat keparahan IMS pada perempuan lebih serius dibandingkan laki-laki. ${ }^{7}$ Pada penelitian ini sebanyak 23,3\% laki-laki terdiagnosis positif IMS, sementara pada perempuan hanya $15,9 \%$ yang terdiagnosis positif. Dalam penelitian ini pasien yang datang ke fasilitas kesehatan dengan keluhan IMS mayoritas adalah perempuan. Hal ini karena perempuan lebih peduli pada kesehatannya dibandingkan laki-laki. Namun IMS pada laki-laki umumnya memiliki gejala klinis yang lebih jelas, dan penegakan diagnosis IMSnya juga lebih mudah.

Dalam penelitian ini dijumpai pula bahwa peluang IMS lebih tinggi pada sampel dengan status menikah. Hal ini sejalan dengan temuan dalam Surveilans Terpadu Biologi dan Perilaku pada Tahun 2011 menyatakan bahwa status pernikahan tertinggi pada pria dengan potensial resiko tinggi adalah menikah sebesar $71 \%{ }^{8}$ Hasil penelitian berdasarkan status perkawinan di Puskesmas II Denpasar Utara tahun 2014 sampai 2016 didapatkan bahwa kejadian IMS lebih tinggi pada subjek yang memiliki status kawin dengan prevalensi sebesar $37,6 \%{ }^{9}$
Dalam penelitian Dyna didapatkan hasil bahwa proporsi penderita IMS berdasarkan status pernikahan tertinggi adalah menikah sebesar $36,7 \% .^{10}$ Laporan dari data statistik Indonesia menyatakan bahwa rata - rata umur perkawinan penduduk berdasarkan jenis kelamin adalah pada usia 26,9 tahun pada laki-laki dan 23,2 tahun pada perempuan. Laki-laki cenderung mengalami IMS pada kelompok umur yang lebih tinggi, yaitu di atas 40 tahun, sementara proporsi penderita IMS pada perempuan tertinggi berada pada kelompok umur 25-29 tahun. Hal ini menunjukkan bahwa sebagian besar penderita IMS yang diperiksa sudah menikah. ${ }^{10}$ Subekti menyatakan bahwa status menikah seseorang tidak menjamin bahwa orang tersebut untuk tidak berganti-ganti pasangan. Beberapa hal yang dapat menyebabkan seseorang untuk bergantiganti pasangan adalah pernikahan yang kurang harmonis, kejenuhan dan banyak permasalahan dalam rumah tangga. ${ }^{11}$

Pelanggan WPS dalam penelitan ini berpeluang terinfeksi IMS lebih tinggi dibandingkan kelompok lain, seperti LSL/ waria, WPS dan lainnya. Hal ini sesuai jika melihat variabel lain yang juga signifikan, antara lain jenis kelamin (pada laki-laki) dan status pernikahan (pada sampel yang sudah menikah). Dimana laki-laki yang sudah menikah dan merupakan pelanggan WPS akan memiliki peluang terinfeksi IMS yang lebih tinggi. Alasan kebutuhan biologis atau hiburan memungkinkan seseorang untuk memiliki lebih dari satu pasangan seksual, terutama mereka yang tinggal jauh atau repisah dari istri, sehingga melampiaskan kebutuhan biologisnya pada pekerja seks. Hal ini menyebabkan kelompok pelanggan WPS lebih 
rentan tertular IMS. ${ }^{12}$

Komisi Penanggulangan AIDS Nasional (KPAN) dalam laporannya menunjukkan bahwa pada kurun waktu antara akhir 1990-an dan awal 2000-an epidemi HIV yang merupakan salah satu dari IMS mengalami peningkatan karena penggunaan napza suntik. ${ }^{13}$ Akan tetapi semakin lama, kecenderungan ini berubah, dimana saat ini jalur utama penularan HIV adalah transmisi seksual, melalui hubungan yang bersifat homoseksual maupun heteroseksual. Pada kenyataannya penularan karena penggunaan napza suntik hampir selalu diikuti oleh perilaku seksual berisiko. Proyeksi kecenderungan epidemi HIV ke depan sampai dengan tahun 2025 menunukkan apabila tidak ada upaya penanggulangan HIV dan AIDS yang berarti, pada tahun 2010 diperkirakan $80 \%$ infeksi baru terjadi terutama melalui transmisi seksual dan sisanya (20\%) karena penggunaan napza suntik. Selain itu proyeksi tersebut juga memperlihatkan epidemik HIV di tahun 2025 yang proporsi tertingginya adalah pada kelompok pelanggan WPS. Hal ini menyebabkan di tahun-tahun mendatang akan ada kecenderungan pergeseran penularan dari lelaki ke perempuan, yang dikenal sebagai feminisasi epidemi HIV. Selanjutnya dari perempuan, penularan akan berlanjut pada bayi. Sehingga secara perlahan jumlah kasus HIV yang awalnya didominasi oleh kaum lakilaki akan meningkat pula pada perempuan.

Kementerian Kesehatan memperkirakan jumlah infeksi HIV yang cukup besar akan terjadi pada laki-laki, terutama mereka yang merupakan pelanggan pekerja seks. Jumlah ini akan disumbangkan dari laki-laki yang sebelumnya telah berhubungan seks dengan WPS, yang kemudian akan menularkan pada istri-istri mereka di rumah. ${ }^{14}$

Kelompok populasi kunci yang lain seperti WPS atau LSL/waria, mengalami peluang terinfeksi yang lebih rendah. Hal ini kemungkinan disebabkan karena program-program IMS dan HIV/AIDS yang tersedia di puskesmas saat ini lebih menyasar pada kelompok tersebut. Misalnya penyuluhan atau mobile VCT yang saat ini ada kebanyakan menyasar WPS dan LSL/ waria. Sementara penjangkauan yang ditujukan bagi pelanggan WPS sangat terbatas.

Dalam penanganan kasus IMS dan HIV di Kota Denpasar, sejak Februari 2009, telah disepakati kelompok kerja (pokja) pencegahan melalui transmisi seksual yang merupakan sebuah intervensi struktural sebagai bentuk kerjasama dengan mucikari di Bali. Pokja tersebut melahirkan beberapa kesepakatan diantaranya mengenai pemakaian kondom, edukasi bagi pegawainya dan sampai saat ini setiap pemilik wajib memeriksakan pegawainya (WPS) IMS setiap bulan sekali. Hal ini mungkin menjadi beberapa faktor penyebab infeksi IMS pada WPS semakin rendah. Akan tetapi, berdasarkan wawancara dengan pemegang program IMS dan HIV di salah satu puskesmas menyatakan, bahwa selain WPSL (wanita pekerja seks langsung) juga terdapat WPSTL (wanita pekerja seks tidak langsung), yang sampai saat ini belum ada pokja yang mengaturnya. Bisa saja beberapa pelanggan WPS mencari layanan WPS pada kelompok ini (WPSTL) sehingga peluang terinfeksi IMS menjadi lebih besar.

Sampel dengan status bekerja memiliki peluang terinfeksi IMS yang lebih besar dibandingkan dengan yang tidak bekerja. Dalam penelitian ini, bekerja antara lain pegawai negeri sipil, menjadi wiraswasta, karyawan swasta. Karyawan swasta yang dimaksud antara lain nelayan, buruh kasar, sopir, ABK, dan sebagainya yang selama ini dikenal sebagai lelaki berisiko tinggi (high risk man). Lebih lanjut Espritio dan Voeten menyatakan bahwa kelompok ini memiliki peran penting pada penularan HIV ke populasi umum, menjadi jembatan penularan HIV untuk wanita pada populasi umum seperi istri atau pacar melalui hubungan seksual dengan WPS. ${ }^{15,16}$ Di Indonesia sendiri kelompok ini diberi label sebagai manusia bergerak dengan uang (3M). Penelitian yang dilakukan oleh Hor dan Lowndes menyimpulkan bahwa upaya untuk mengurangi risiko infeksi HIV pada pelanggan dari WPS mungkin memiliki dampak yang cukup besar dalam memperlambat penyebaran epidemi HIV. ${ }^{17,18}$

Dalam penelitian ini diperoleh bahwa variabel yang secara statistik tidak terbukti mempengaruhi kejadian IMS adalah variabel umur. Golongan umur dengan insiden IMS yang meningkat adalah golongan umur dengan kegiatan seksual aktif. Hal ini menyesuaikan dengan cara penularan penyakit menular seksual 
yaitu melalui kontak seksual. ${ }^{7}$ Hasil penelitian ini berbeda dengan penelitian Budiman, dkk yang menyatakan bahwa mereka yang berumur 20-34 tahun berisiko tinggi terkena IMS dibandingkan mereka yang berumur $<20$ atau $>34$ tahun. ${ }^{19}$ Dalam penelitian ini diperoleh bahwa pelanggan WPS, laki-laki, status menikah dan bekerja memiliki peluang terinfeksi IMS yang lebih besar. Sehingga penularan IMS dalam penelitian ini mungkin lebih mengarah pada sampel yang berusia $>35$ tahun, meskipun tidak bermakna secara statistik. Hasil penelitian ini sesuai dengan penelitian Dewi di Puskesmas II Denpasar Utara tahun 2014 sampai 2016, dimana ditemukan kejadian IMS lebih tinggi pada kelompok umur 41-50 tahun dengan prevalensi sebesar $25 \% .{ }^{9}$ Hasil penelitian ini juga berbeda dengan hasil penelitian CDC pada tahun 2010 yang menemukan bahwa risiko IMS tertinggi adalah pada kelompok umur 15-19 tahun, disusul 20-24 tahun. Perbedaan ini kemungkinan disebabkan oleh adanya perbedaan budaya dan gaya hidup. Pada remaja-remaja di Amerika, hubungan seks pranikah lebih umum dilakukan daripada di Indonesia yang menyebabkan paparan IMS di usia yang lebih muda pada masyarakat Amerika lebih tinggi daripada masyarakat di Indonesia. ${ }^{3}$

Pada variabel pendidikan, tidak ditemukan pengaruh antara pendidikan dengan kejadian IMS. Hasil penelitian ini berbeda dengan hasil penelitian Nova yang menemukan terdapat hubungan antara pendidikan dengan kejadian IMS. ${ }^{20}$ Lebih lanjut dalam penelitian tersebut ditemukan bahwa responden dengan pendidikan lebih rendah memiliki risiko mengalami IMS yang lebih tinggi. Hasil penelitian juga menunjukkan tidak ada pengaruh antara pemakaian kondom pada hubungan seksual terakhir dengan kejadian IMS. Hasil penelitian ini berbeda dengan penelitian Arifin yang menyatakan bahwa penggunaan kondom yang tidak konsistensi merupakan faktor risiko untuk terjadinya IMS sebesar 1,8 kali lebih tinggi. ${ }^{21}$ Dalam penelitian ini, hanya dicari data pemakaian kondom pada hubungan seksual terakhir, bukan konsistensi penggunaan kondomnya. Hal ini menyebabkan infeksi IMS didapatkan bukan dari hubungan seksual terakhirnya, yang menjadi penyebab perbedaan hasil penelitian.

\section{KESIMPULAN}

Insiden kasus IMS di Kota Denpasar selama tahun 2016 sebesar 18,2\%. Peluang untuk terinfeksi IMS ditemukan lebih tinggi pada pelanggan WPS, berstatus bekerja, berjenis kelamin laki-laki dan berstatus menikah. Strategi penjangkauan lapangan yang selama ini hanya ditujukan kepada WPS dan LSL/waria, diharapkan dapat pula menjangkau pelanggan WPS. Selain itu, pokja yang ada selama ini hanya menyasar WPSL, belum menyasar WPSTL. Diharapkan pokja yang menyasar WPSTL juga dapat dibentuk, sehingga tidak hanya dapat mengurangi infeksi HIV bagi mereka sendiri, namun juga bagi pelanggan dan masyarakat umum seperti istri dan anaknya.

\section{UCAPAN TERIMA KASIH}

Ucapan terima kasih kami sampaikan kepada para pemegang program IMS di masing-masing puskesmas yang menjadi lokasi penelitian.

\section{DAFTAR RUJUKAN}

1. Mayaud P,Mabey D. Approaches to the control of sexually transmitted infection on developing countries: old problem and modern challenges. BMJ. 2004;80:174-182.

2. World Health Organization. Sexually transmitted infections, Geneva: WHO; 2011.

3. Centers for Disease Control and Prevention. Sexually transmitted disease surveillance. Atlanta US: Department of Health and Human Services, Division of STD Prevention; 2013.

4. Kusnan, A. Analisis hubungan determinan kejadian penyakit infeksi menular seksual (IMS) pada wanita penjaja seksual (WPS) [skripsi[. Sulawesi Tenggara: Fakultas Kesehatan Masyarakat Universitas Halu Oleo; 2013.

5. SDKI, Survei demografi dan kesehatan Indonesia 2012. Jakarta: Badan Pusat Statistik; 2013.

6. Dinas Kesehatan Kota Denpasar. Profil Dinas Kesehatan Kota Denpasar Tahun 
2012. Denpasar: Dinas Kesehatan Kota Denpasar; 2013.

7. Setyawulan. Hubungan praktek pencegahan penyakit menular seksual dengan kejadian penyakit menular seksual [skripsi]. Semarang; Universitas Muhammadiyah Semarang; 2007.

8. Kementerian Kesehatan Republik Indonesia. Survei terpadu biologis dan perilaku 2011. Jakarta: Kemenkes RI; 2012.

9. Dewi, Y. Kejadian infeksi menular seksual (IMS) berdasarkan karakteristik sosial demografi di Puskesmas II Denpasar Utara Tahun 2014-2016 [skripsi]. Denpasar: Universitas Udayana; 2016.

10. Dyna, S., dkk. Karakteristik Penderita Infeksi Menular Seksual Di Wilayah Kerja Puskesmas Bandar Baru Tahun 2013 [skripsi]. Sumatera Utara: Departemen Epidemiologi FKM USU; 2013.

11. Subekti, R. Hubungan Umur dan Status Perkawinan dengan Kejadian Gonore di Puskesmas Madukara I Kabupaten Banjarnegara Tahun 2015. Medsaina. 2017;3(1):1-5.

12. Ekawati, N.K., dkk. Laporan hasil penelitian studi tentang perilaku beresiko pelaku pekerja pariwisata (sopir travel dan pramuwisata) terhadap HIV/AIDS di Kota Denpasar Provinsi Bali. Denpasar: Fakultas Kedokteran Universitas Udayana; 2014.

13. Komisi Penanggulangan AIDS Nasional. Laporan KPA Nasional 2010. Jakarta: KPAN; 2010.

14. Kementerian Kesehatan Republik Indonesia. Estimasi dan Proyeksi HIV/AIDS di Indonesia Tahun 2011-2016. Jakarta: Kemenkes RI; 2014.
15. Espirito Santo M, Etheredge G. How to reach clients of female sex workers: a survey" by surprise" in brothels in Dakar, Senegal. Bulletin of the World Health Organization. 2002;80(9):709-713.

16. Voeten HA, Egesah OB, Ondiege MY, Varkevisser CM, Habbema JDF. Clients of female sex workers in Nyanza province, Kenya: a core group in STD/ HIV transmission. Sexually Transmitted Diseases. 2002;29(8):444-452.

17. Hor LB, Detels R, Heng S, Mun P. The role of sex worker clients in transmission of HIV in Cambodia. International Journal of STD \& AIDS. 2005;16(2):170-174.

18. Lowndes CM, Alary M, Labbe A-C, et al. Interventions among male clients of female sex workers in Benin, West Africa: an essential component of targeted HIV preventive interventions. Sexually Transmitted Infections. 2007;83(7):577581.

19. Budiman, dkk. Faktor-faktor yang berhubungan dengan kejadian gonore di wilayah kerja Puskesmas Ibrahim Adjie Kota Bandung. Bandung: Universitas Islam Bandung; 2015.

20. Nova. Hubungan pendidikan dan pengetahuan dengan kejadian penyakit menular seksual pada klien di wilayah kerja Puskesmas Penurunan Kota Bengkulu Tahun 2014. [skripsi]. Bengkulu: Akademi Kesehatan Sapta Bakti Bengkulu; 2015.

21. Arifin, N.F. Penggunaan kondom dan vaginal higiene sebagai faktor risiko kejadian infeksi menular seksual pada wanita pekerja seks di lokasi Batu 24 Kabupaten Bintan. Semarang: Universitas Diponegoro; 2012. 